\title{
Heart regeneration: The endothelial cell comes first
}

\author{
Megumi Mathison, MD, PhD, ${ }^{\mathrm{a}}$ and Todd K. Rosengart, MD, FACS ${ }^{\mathrm{a}, \mathrm{b}}$

\footnotetext{
From the a Division of Cardiothoracic Surgery, Michael E. DeBakey Department of Surgery, Baylor College of Medicine; and the ${ }^{\mathrm{b}}$ Department of Cardiovascular Surgery, Texas Heart Institute, Houston, Tex.

This study was funded by the National Heart, Lung, and Blood Institute (1R01HL121294-01A1[to T.K.R.]).

Disclosures: Authors have nothing to disclose with regard to commercial support.

Received for publication Sept 19, 2017; accepted for publication Sept 22, 2017.

Address for reprints: Todd K. Rosengart, MD, FACS, 1 Baylor Plaza, MS 390, Houston, TX 77030 (E-mail: todd. rosengart@bcm.edu).

J Thorac Cardiovasc Surg 2018;155:1128-9

$0022-5223 / \$ 36.00$

Copyright (c) 2017 Published by Elsevier Inc. on behalf of The American Association for Thoracic Surgery

https://doi.org/10.1016/j.jtcvs.2017.09.106
}

Although great therapeutic progress in treating cardiovascular disease has been achieved in recent years, heart failure after ischemic heart disease remains the leading cause of death of people older than 65 years in the United States. ${ }^{1}$ The fundamental challenge to treating postinfarct heart failure is that neither the noncontractile, fibrotic scar tissue that replaces ischemic or necrotic cardiomyocytes after myocardial ischemic or infarction events nor the residual native myocardial tissue readily naturally serves as a substrate for myocardial regeneration. ${ }^{2}$ Several strategies have consequently been pursued by cardiac researchers to overcome the limited regenerative capability of the human heart: (1) increasing the regenerative capability of the cardiomyocytes by inducing cell division or recruiting endogenous stem cells or progenitor cells $^{3-5}$; (2) implantation of cardiomyocytes or progenitor cells that may differentiate into cardiomyocytes ${ }^{6-8}$; and (3) in situ reprogramming of cardiac fibroblasts into cardiomyocytes.

Each of these myocardial regeneration strategies has advantages and disadvantages, and further investigation is warranted before the use of any of them can be supported as a viable clinical therapy. One principle that appears to unify all these regenerative strategies is addressing the challenge that any newly generated cardiomyocytes will be located in the ischemic postinfarct environment and will therefore need an augmented source of oxygenated blood to survive. Given this dilemma, we previously demonstrated that angiogenic pretreatment of myocardial scar (with vascular endothelial growth factor) increased scar vascularization and the subsequent cardiac functional improvements rendered by the subsequent administration of cardiac reprogramming factors that have been shown to transdifferentiate scar fibroblasts into induced cardiomyocytes. ${ }^{10}$ This work recapitulates similar examples of the benefits of angiogenic pretreatment or cotreatment of scarred myocardium accompanying the use of stem cell administration. $^{11-13}$

Ingason and colleagues ${ }^{14}$ report in this issue of The Journal of Thoracic and Cardiovascular Surgery their

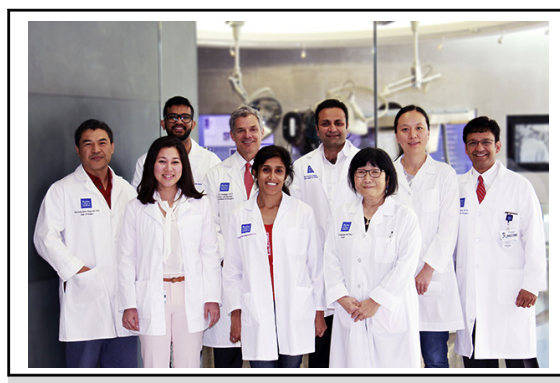

Dr Rosengart's Cardiac Regeneration Lab in Baylor College of Medicine.

Central Message

Endothelial cells play an essential role in cardiomyocyte regeneration, not only supplying perfusion but also guiding cardiomyocytes for migration and organization.

See Article page 1118 .

findings that angiogenesis preceded cardiomyocyte migration in a neonatal mouse apical resection model. They concluded that preestablishment of the vasculature is paramount to supporting cardiomyocyte ingrowth and survival, similar to the previous observations of Porrello and associates. ${ }^{15,16}$ These findings are reminiscent of the therapeutic principles noted with angiogenic pretreatment of myocardial scar.

The concept that cardiomyocyte ingrowth more specifically follows the "guidance" of endothelial cells has been suggested by Narmoneva and coworkers, ${ }^{17}$ who demonstrated that cardiomyocyte reorganization occurs along endothelial cell and capillarylike networks. In addition, cardiomyocytes started synchronized, spontaneous contraction when cultured in the preformed endothelial cell network, in contrast to cardiomyocyte-only culture, in which such contraction was much less.

The findings of Ingason and colleagues ${ }^{14}$ suggest the important principle that endothelial cells play an essential role in cardiomyocyte regeneration in the postinfarct heart, not only by supplying perfusion to the infarcted myocardium but also in the way that endothelial cells guide cardiomyocyte organization. The role of the endothelial cell must therefore be taken into account no matter what approach is taken to regenerate cardiomyocytes in the infarcted heart. The addition of endothelial cells or endothelial development strategies to myocardial regenerative strategies must be seriously considered if we are to improve the efficiency of heart regeneration. 


\section{References}

1. National Center for Health Statistics. Health, United States, 2016: With Chartbook on Long-term Trends in Health. Hyattsville, MD: National Center for Health Statistics; 2017.

2. Sutton MG, Sharpe N. Left ventricular remodeling after myocardial infarction: pathophysiology and therapy. Circulation. 2000;101:2981-8.

3. Tao G, Kahr PC, Morikawa Y, Zhang M, Rahmani M, Heallen TR, et al. Pitx2 promotes heart repair by activating the antioxidant response after cardiac injury. Nature. 2016;534:119-23.

4. Wen Z, Mai Z, Zhang H, Chen Y, Geng D, Zhou S, et al. Local activation of cardiac stem cells for post-myocardial infarction cardiac repair. J Cell Mol Med. 2012;16:2549-63.

5. Finan A, Richard S. Stimulating endogenous cardiac repair. Front Cell Dev Biol. 2015;3:57.

6. Chong JJ, Yang X, Don CW, Minami E, Liu YW, Weyers JJ, et al. Human embryonic-stem-cell-derived cardiomyocytes regenerate non-human primate hearts. Nature. 2014;510:273-7.

7. Dawn B, Tiwari S, Kucia MJ, Zuba-Surma EK, Guo Y, Sanganalmath SK, et al, Transplantation of bone marrow-derived very small embryonic-like stem cells attenuates left ventricular dysfunction and remodeling after myocardial infarction. Stem Cells. 2008;26:1646-55.

8. Tokunaga M, Liu ML, Nagai T, Iwanaga K, Matsuura K, Takahashi T, et al. Implantation of cardiac progenitor cells using self-assembling peptide improves cardiac function after myocardial infarction. J Mol Cell Cardiol. 2010;49: 972-83.

9. Qian L, Huang Y, Spencer CI, Foley A, Vedantham V, Liu L, et al. In vivo reprogramming of murine cardiac fibroblasts into induced cardiomyocytes. Nature. 2012;485:593-8.

10. Mathison M, Gersch RP, Nasser A, Lilo S, Korman M, Fourman M, et al. In vivo cardiac cellular reprogramming efficacy is enhanced by angiogenic preconditioning of the infarcted myocardium with vascular endothelial growth factor. J Am Heart Assoc. 2012;1:e005652.

11. Retuerto MA, Schalch P, Patejunas G, Carbray J, Liu N, Esser K, et al. Angiogenic pretreatment improves the efficacy of cellular cardiomyoplasty performed with fetal cardiomyocyte implantation. J Thorac Cardiovasc Surg. 2004;127: 1041-9; discussion 1049-51.

12. Retuerto MA, Beckmann JT, Carbray J, Patejunas G, Sarateanu S, Kane BJ, et al Angiogenic pretreatment to enhance myocardial function after cellular cardiomyoplasty with skeletal myoblasts. J Thorac Cardiovasc Surg. 2007;133: 478-84.e2.

13. Miyagawa S, Sawa Y, Taketani S, Kawaguchi N, Nakamura T, Matsuura N, et al. Myocardial regeneration therapy for heart failure: hepatocyte growth factor enhances the effect of cellular cardiomyoplasty. Circulation. 2002;105: 2556-61.

14. Ingason AB, Goldstone AB, Paulson MJ, Thakore A, Truong V, Edwards BB et al. Angiogenesis precedes cardiomyocyte migration in regenerating mammalian hearts. J Thorac Cardiovasc Surg. 2018;155:1118-27.

15. Porrello ER, Mahmoud AI, Simpson E, Hill JA, Richardson JA, Olson EN, et al. Transient regenerative potential of the neonatal mouse heart. Science. 2011;331: 1078-80.

16. Porrello ER, Mahmoud AI, Simpson E, Johnson BA, Grinsfelder D, Canseco D et al. Regulation of neonatal and adult mammalian heart regeneration by the miR 15 family. Proc Natl Acad Sci U S A. 2013;110:187-92.

17. Narmoneva DA, Vukmirovic R, Davis ME, Kamm RD, Lee RT. Endothelial cells promote cardiac myocyte survival and spatial reorganization: implications for cardiac regeneration. Circulation. 2004;110:962-8. 